\title{
Aplikasi Inseminasi Buatan pada Induk Sapi Potong Menggunakan Semen Cair Sapi Peranakan Ongole dengan Pengencer Cauda Epidydymal Plas- ma-2 + 0,6\% Bovine Serum Albumin
}

\section{Application of Artificial Insemination on Beef Cattle using Liquid Semen of Ongole Cross Bred Bull with Epidydymal Cauda Plasma-2 Diluent $+\mathbf{0 . 6 \%}$ Bovine Serum Albumin}

\author{
Achadiah Rachmawati ${ }^{1,2) *}$, Ismaya ${ }^{1)}$, Budi Prasetyo Widyobroto ${ }^{3)}$, Sigit Bintara ${ }^{1)}$ dan Trinil \\ Susilawati ${ }^{4}$ * \\ ${ }^{1)}$ Laboratorium Fisiologi Reproduksi Ternak, Fakultas Peternakan, Universitas Gadjah Mada \\ ${ }^{2}$ Laboratorium Fisiologi Ternak, Fakultas Peternakan, Universitas Brawijaya, Malang \\ ${ }^{3)}$ Laboratorium Ternak Perah dan Industri Susu, Fakultas Peternakan, Universitas Gadjah Mada \\ 4)Laboratorium Reproduksi Ternak, Fakultas Peternakan, Universitas Brawijaya, Malang
}

Submitted: 7 Oktober 2018, Accepted: 7 Desember 2018

\begin{abstract}
ABSTRAK: Artificial insemination (AI) in cattle using Ongole Cross Breed liquid semen with cauda epidydymal plasma-2 (CEP-2) diluent+0.6\% Bovine Serum Albumin (BSA) aimed to improve the genetic quality of livestock with high sperm motility on beef cows. Addition of BSA as extracellular cryoprotectant to support egg yolk function to prevent membrane damage caused by cold shock during cold storage. This research was conducted in Tumpang, Pakis, and Singosari Sub-district, Malang Regency using 38 cows that inseminated using frozen semen of Limousine and Simmental breeds as control (19 cows) and liquid semen with CEP-2 $+0.6 \%$ BSA as a treatment (19 cows). The reproductive parameters were Non Return Rate (NRR), Service per Conception (S/C) and Conception Rate (CR). Data were analyzed descriptively and continued by chi-square test. The results showed that insemination using frozen and liquid semen did not affect the success rate of AI in beef cows. The NRR $\mathrm{N3}_{43}$ value of frozen was $89.40 \%$ and liquid semen was $78.94 \%$; the CR value of frozen semen was $84.21 \%$ and liquid semen was $57.89 \%$; and the $\mathrm{S} / \mathrm{C}$ value of frozen semen was 1.21 and liquid semen was 1.42 . The conclusions of the study were the values of $\mathrm{NRR}_{43-63}, \mathrm{CR}$ and $\mathrm{S} / \mathrm{C}$ of frozen higher than liquid semen.
\end{abstract}

Keywords: Non Return Rate (NRR); Service per Conception (S/C); Conception Rate (CR).

ABSTRACT: Inseminasi buatan (IB) pada sapi menggunakan semen cair sapi peranakan ongole (PO) dengan pengencer CEP-2+0,6\% BSA untuk meningkatkan kualitas genetik ternak dengan motilitas spermatozoa yang tinggi pada sapi potong. Penambahan BSA sebagai extracellular cryoprotectantdalam mendukung fungsi kuning telur untuk mencegah kerusakan membran yang disebabkan oleh kejutan dingin selama penyimpanan dingin. Penelitian dilaksanakan di Kecamatan Tumpang, Pakis dan Singosari Kabupaten Malang menggunakan 38 ekor sapi yang diinseminasi dengan semen beku sapi Limousine dan Simmental sebagai kontrol (19 ekor) dan semen cair Sapi PO dengan pengencer CEP-2 + 0,6\% BSA sebagai perlakuan (19 ekor). Parameter reproduksi yang diamati adalah non return rate (NRR), service per conception $(\mathrm{S} / \mathrm{C})$ dan conception rate $(\mathrm{CR})$. Data dianalisis secara deskriptif dan dilanjutkan dengan uji chi-square. Hasil penelitian menunjukkan bahwa inseminasi menggunakan semen beku dan cair tidak mempengaruhi keberhasilan IB pada sapi potong. Nilai NRR 43-63 dari semen beku sebesar 89,40\% dan semen cair sebesar 78,94\%; Nilai CR semen beku sebesar $84,21 \%$ dan semen cair sebesar 57,89\%; dan nilai S/C semen beku sebesar1,21 dan semen cair sebesar 1,42. Kesimpulan dari penelitian ini adalah nilai NRR ${ }_{43-63}$, CR dan S/C semen beku lebih tinggi dari semen cair.

Kata Kunci : Non Return Rate (NRR); Service per Conception (S/C); Conception Rate (CR).

*Corresponding Author: achadiahr@ub.ac.id and trinil_susilawati@yahoo.com

DOI: 10.21776/ub.jiip.2018.028.03.08 


\section{PENDAHULUAN}

Persilangan antara sapi lokal dengan pejantan unggul Sapi Ongole menghasilkan Sapi PO atau disebut Ongolisasi yang mulai dilakukan sejak Pemerintahan Hindia Belanda (Supartini dan Darmawan, 2014). Sapi PO memberikan kontribusi yang besar dalam pemenuhan kebutuhan pangan protein hewani di Indonesia. Keberadaan Sapi PO sebagai plasma nutfah nasional harus tetap dipertahankan untuk produktif. Sapi PO merupakan salah satu sumber daya genetik (SDG) lokal Indonesia yang banyak dikembangbiakkan di Jawa Timur dan dikenal sebagai sapi pedaging maupun pekerja. Keunggulan sapi PO adalah mempunyai kemampuan adaptasi yang tinggi terhadap lingkungan tropis yang panas, memiliki tenaga yang kuat dan aktifitas reproduksi induk cepat kembali normal setelah melahirkan. Sapi PO jantan memiliki kualitas semen yang baik (Ratnawati et al.,2016).

Guna mendukung Program Ongolisasi di Propinsi Jawa Timur (Supartini dan Darmawan, 2014) dan Upaya Khusus Sapi Indukan Wajib Bunting (UPSUS SIWAB) untuk percepatan target pemenuhan populasi sapi potong dalam negeri dan Swasembada Daging Tahun 2026, yaitu meningkatkan populasi dan mutu genetik Sapi PO melalui bioteknologi Inseminasi Buatan (IB) dan Intensifikasi Kawin Alam (Inka). Inseminasi Buatan (IB) merupakan salah satu teknologi reproduksi yang mampu untuk meningkatkan mutu genetik ternak, sehingga dalam waktu pendek dapat menghasilkan anak dengan kualitas baik dalam jumlah yang besar dengan memanfaatkan pejantan unggul (Susilawati, 2013). Faktanya, persilangan antara sapi lokal dengan sapi eksotik (Simmental dan Limousine) sering dilakukan di Indonesia untuk mendapatkan bobot lahir anak tinggi dan diikuti dengan harga jual yang tinggi. Persilangan dengan sapi eksotik tersebut menyebabkan penurunan produktifitas dan daya adapatasi terhadap lingkungan tropis yang panas.

Inseminasi Buatan akan berhasil dengan baik, apabila didukung oleh semen yang berkualitas, baik semen cair maupun beku. Prosesing semen cair dan beku harus didukung oleh pengencer yang mampu mempertahankan kualitas semen selama penyimpanan dingin $\left(5^{\circ} \mathrm{C}\right)$. Pengenceran semen bertujuan untuk menambah volume dari setiap ejakulat dan memberi zat-zat nutrisi yang dibutuhkan untuk mempertahankan viabilitas dan fertilitas spermatozoa, memberikan perlindungan terhadap spermatozoa terhadap kejutan dingin (cold shock), mencegah berkembangnya mikroorganisme dan sebagai penyangga (buffer) dalam menjaga kestabilan $\mathrm{pH}$ (Aboagla and Terada, 2004; Peris et al., 2007 and Simbolon, Lubis dan Adam., 2013). Pengencer harus mempunyai sifatsifat seperti seminal plasma yang dapat menciptakan kondisi spermatozoa bertahan hidup dalam kondisi buatan selama proses penyimpanan.

Pengencer yang sedang berkembang saat ini adalah pengencer CEP2yangmemiliki komposisi kimia, seperti $\mathrm{NaCl}, \quad \mathrm{KCl}, \quad \mathrm{CaCl}_{2}\left(\mathrm{H}_{2} \mathrm{O}\right)_{6}, \quad \mathrm{NaH}_{2} \mathrm{PO}_{4}$, $\mathrm{KH}_{2} \mathrm{PO}_{4}$, fruktosa, sorbitol, tris, gentamicin, asam sitrat dan osmolaritas yang sama dengan keadaan seminal plasma didalam cauda epidydymis (Verberckmoes et al., 2004). Pengencer CEP-2 tidak mengandung antioksidan yang melindungi spermatozoa dari radikal bebas atau reactive oxygen species (ROS) yang menyebabkan kerusakan DNA, karbohidrat, lipid, asam nukleat dan protein didalam nukleus dan membrane sel (Lobo et al., 2010).

Prosesing semen, seperti pendinginan, menyebabkan kerusakan membran berakibat pada kematian spermatozoa lebih dari 50\% (Delgado, Lester dan Rorie, 2009 dan Kaeoket et al., 2011). Penyimpanan spermatozoa pada suhu dingin $\left(5^{\circ} \mathrm{C}\right)$ merupakan metode alternatif yang murah, praktis, efisien dan tidak membutuhkan nitro- 
gen cair, karena penyediaan, transportasi dan regulasi mudah serta meningkatkan jumlah betina yang diinseminasidengan dosis IB rendah (Gillan, Maxwell dan Evans, 2004 dan Ponglowhapana et al., 2004).

Penambahan albumin, seperti BSA, sebagai extracellular membrane dalam pengencer CEP-2 diharapkan mampu mempertahankan fungsi membran yang berhubungan dengan kualitas spermatozoa. Kandungan BSA dalam CEP-2 merupakan makromolekul yang berperan mengikat ion $\mathrm{Ca}^{2+}$, mencegah masuknya ion $\mathrm{Ca}^{2+}$ berlebihan ke sitosol, memungkinkan membran untuk lebih efektif dalam mengatur pergerakan ion $\mathrm{Ca}^{2+}$ melewati membran dan menghambat akumulasi ion $\mathrm{Ca}^{2+}$ intraseluler ke tingkat toksik bagi spermatozoa, sehingga viabilitas, motilitas dan jumlah spermatozoa belum terkapasitasi dapat dipertahankan tetap tinggi (LandimAlvarenga et al., 2004). Yamashiro et al. (2006) menjelaskan bahwa penambahan 5\% BSA dalam pengencer Tris (hydroxymethyl-aminomethane)-citric acidglucose pada spermatozoakambing Shiba post-thawingmenghasilkan motilitas yang lebih tinggi $(77,3 \pm 3,7) \%$ dibandingkan dengan spermatozoa tanpa BSA $(58,6 \pm 5,9) \%$. Penelitian Osman, et al. (2012) melaporkan bahwa viabilitas spermatozoa sapi Piedmontese sebesar $(38,743 \pm 0,854) \%$ setelah penyimpanan pada suhu $4^{\circ} \mathrm{C}$ selama 31 hari dengan level BSA $8 \mathrm{mg} / \mathrm{ml}$. Level BSA yang digunakan adalah $0,1,4,8,12$, and $16 \mathrm{mg} / \mathrm{ml}$ BSA dalam pengencer BIOXcell ${ }^{\circledR}$ (IMV Technologies, L'Agile, France).

Penelitian Susilawati (2017) menjelaskan bahwa spermatozoa sapi PO yang disimpan dengan pengencer CEP-2 $+10 \%$ kuning telur dapat bertahan di dalam penyimpanan dingin $2-4{ }^{\circ} \mathrm{C}$ selama delapan hari. Aplikasi IB dengan semen beku dan cair pada Sapi PO dilakukan oleh Susilawati, et al. (2016) menggunakan pengencer Tris Aminomethane $+10 \%$ kuning telur menghasilkan nilai S/C sebesar

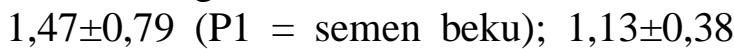
$(\mathrm{P} 2$ = menggunakan semen cair dengan

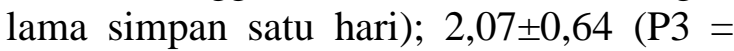
semen beku) dan 1,17 $\pm 0,38(\mathrm{P} 4=$ semen cair dengan lama simpan lima hari). Inseminasi Buatan menggunakan semen cair dan beku dengan pengencer CEP-2 dengan BSA belum di aplikasikan di lapang.

Penelitian tentang aplikasi semen cair dan beku pada Sapi PO menggunakan pengencer CEP-2 dengan BSA sebagai extracellular cryoprotectant belum dilakukan. Hasil penelitian tentang aplikasi IB menggunakan semen cair tersebut diharapkan mendukung Program UPSUS SIWAB dalam rangka meningkatkan mutu genetik ternak.

\section{MATERI DAN METODE}

\section{Lokasi dan Waktu Penelitain}

Penelitian dilaksanakan bulan September 2017 sampai April 2018 di Kecamatan Tumpang, Pakis dan Singosari, Kabupaten Malang untuk aplikasi IB menggunakan semen cair dan beku. Pembuatan pengencer CEP-2 dilakukan di Laboratorium Reproduksi Ternak, Fakultas Peternakan, Universitas Brawijaya, Malang. Penampungan semen, evaluasi kualitas dan prosesing semen cair di Laboratorium Reproduksi dan Nutrisi Makanan Ternak, Loka Penelitian Sapi Potong, Kecamatan Grati, Kabupaten Pasuruan.

\section{Materi}

Materi yang digunakan dalam penelitian adalah 38 ekor induk sapi potong, terdiri dari 19 ekor yang diinseminasi dengan semen beku (kontrol-P1) Sapi Limousine dan Simmental diproduksi oleh Balai Besar Inseminasi Buatan, Lembang (menggunakan pengencer Skim Milk dan nilai post thawing motility $(\mathrm{PTM}) \geq 40 \%$ ) sebagai kontrol dan 19 ekor di inseminasi dengan semen cair sapi PO (P2) menggunakan Pengencer CEP-2+ 0,6\% BSA (nilai $\mathrm{PTM} \geq 30 \%$ ). Sampel sapi 
potong induk yang dipilih secara purposive sampling dengan kriteria sapi yang sudah pernah melahirkan, tidak mengalami gangguan reproduksi, posisi 4+ dan memiliki kondisi birahi, yaitu labia minora memerah, vulva membengkak,suhu tubuh meningkat dan keluar lendir berwarna bening.

\section{Metode}

Metode yang digunakan dalam penelitian ini adalah percobaan lapang dan observasi langsung. Thawingsemen beku menggunakan air dengan suhu $37^{\circ} \mathrm{C}$ selama 15 detik. Pengambilan data dilakukan dengan observasilangsung di lapang, meliputi: bangsa ternak, umur ternak berkisar 1,5-5 tahun, breed, Body Condition Score
(BCS) yang berkisar antara 2-5 dengan rentang penilaian 1-9 dan manajemen pemeliharaan. Wawancara langsung dengan peternak, meliputi: tanggal IB, tanggal birahi dan inseminator, meliputi: riwayat reproduksi dan kesehatan ternak.

Variabel yang diamati untuk menentukan keberhasilan IB adalah non return rate (NRR), service per conception $(\mathrm{S} / \mathrm{C})$ dan conception rate $(\mathrm{CR})$.

\section{Non return rate (NRR)}

Nilai NRR merupakan persentase sapi akseptor IB yang tidak kembali birahi selama 20-60 hari atau 60-90 hari setelah pelaksanaan IB (Susilawati, 2011 ${ }^{\mathrm{a}}$ ). Iswoyo dan Widiyaningrum (2008) menjelaskan bahwa rumus menentukan NRR, yaitu:

$\operatorname{NRR}(\%)=\frac{\text { jumlah sapi yang di inseminasi }- \text { jumlah sapi yang di inseminasi kembali }}{\text { jumlah seluruh sapi yang di inseminasi }} \times 100 \%$

\section{Service per Conception conception} (S/C)

Nilai S/C adalah angka yang menunjukkan jumlah sapi akseptor IB yang di in- seminasi untuk mendapatkan hasil kebuntingan. Royal et al. (2000) menyatakan bahwa nilai S/C dapat dihitung menggunakan rumus, sebagai berikut:

$$
\mathrm{S} / \mathrm{C}=\frac{\text { jumlah inseminasi (service) sampai terjadi kebuntingan }}{\text { jumlah akseptor yang bunting }}
$$

\section{Conception rate $(\mathrm{CR})$}

Nilai CR merupakan persentase sapi betina yang berhasil bunting pada IB pertama dan disebut juga sebagai angka konsepsi (Susilawati, 2011 ${ }^{\mathrm{a}}$ ). Susilawati (2005) menjelaskan bahwa nilai CR dapat dihitung menggunakan rumus, sebagai berikut:

$$
\mathrm{CR}(\%)=\frac{\text { jumlah akseptor yang bunting pada inseminasi pertama }}{\text { jumlah seluruh akseptor }} \times 100 \%
$$

Data dari hasil penelitian yang diperoleh selanjutnya dianalisis dengan diskriptif dan statistik menggunakan uji Chi- Square sesuai dengan pendapat Supranto (2012) adalah:

$$
x^{2}=\sum \frac{(f 0-f h) 2}{f h}
$$

Keterangan:

$x^{2}=$ chi-square

$f O=$ frekuensi berdasarkan data

$f h=$ frekuensi yang diharapkan 
Tabel 1. Hasil uji kualitas semen segar Sapi PO selama penelitian

\begin{tabular}{ll}
\hline Parameter & Rataan \\
\hline Makroskopis & \\
Volume $(\mathrm{ml})$ & $1,5 \pm 0,79$ \\
Warna & Putih susu \\
Bau & Khas ternak \\
pH & $7 \pm 0$ \\
Konsistensi & Sedang \\
Mikroskopis & \\
Motilitas massa & $2+$ \\
Motilitas individu $(\%)$ & $52,27 \pm 4,67$ \\
Viabilitas $(\%)$ & $76,81 \pm 5,56$ \\
Abnormalitas $(\%)$ & $24,03 \pm 0,99$ \\
Konsentrasi $\left(10^{6} / \mathrm{ml}\right)$ & $1391,81 \pm 254,35$ \\
\hline
\end{tabular}

HASIL DAN PEMBAHASAN

Evaluasi Hasil IB bedasarkan Nilai NRR

Penilaian NRR berpedoman pada sapi yang di inseminasi dan tidak birahi lagi, maka dianggap bunting. Nilai NRR yang diperoleh dengan pengamatan birahi pada hari ke-21,42 dan 63 setelah IB disajikan pada Tabel 2.

Tabel 2. Data NRR1 $1_{(19-21,)}$ NRR $2_{(22-42)}$ dan NRR 3(43-63)

\begin{tabular}{|c|c|c|c|c|c|c|c|c|}
\hline \multirow{2}{*}{ No } & \multirow{2}{*}{ Jenis semen } & \multirow{2}{*}{$\begin{array}{l}\text { Jumlah Induk } \\
\text { (ekor) }\end{array}$} & \multicolumn{2}{|c|}{ NRR1 } & \multicolumn{2}{|c|}{ NRR2 } & \multicolumn{2}{|c|}{ NRR3 } \\
\hline & & & $\mathrm{n}$ & $\%$ & $\mathrm{n}$ & $\%$ & $\mathrm{n}$ & $\%$ \\
\hline 1. & $\begin{array}{l}\text { Beku Kontrol } \\
\text { (P1) }\end{array}$ & 19 & 18 & 94,73 & 18 & 94,73 & 17 & 89,40 \\
\hline 2. & Cair (P2) & 19 & 18 & 94,73 & 16 & 84,21 & 15 & 78,94 \\
\hline
\end{tabular}

$\mathrm{n}=$ jumlah ternak yang bunting $\mathrm{n}=$ jumlah ternak yang bunting $\mathrm{n}=$ jumlah ternak yang bunting $\mathrm{n}=$ jumlah ternak yang bunting

Berdasarkan analisis statistik menunjukkan bahwa IB menggunakan semen beku dan cair tidak berbeda nyata. Rendahnya nilai NRR pada semen cair diduga disebabkan oleh peningkatan suhu pada semen cair pada saat proses pengemasan ke dalam straw secara manual. Penyebab lain rendahnya nilai NRR disebabkan oleh beberapa faktor, yaitu deteksi birahi peternak kurang akurat, ketepatan waktu IB, kualitas dan kuantitas pakan dan kualitas semen beku maupun cair yang diinseminasikan ke ternak betina. Kekurangan protein dalam ransum ternak betina dapat menyebabkan birahi kembali. Hal ini didukung oleh pendapat Susilawati $\left(2011^{a}\right)$ bahwa hasil ratarata NRR pada hari ke-60-90 sebesar 90\% dari empat perlakuan dengan sampel sapi
10 ekor tiap perlakuan dan mengalami penurunan nilai NRR.

Kualitas birahi merupakan salah satu indikator yang mempengaruhi tinggi rendahnya nilai NRR. Sapi yang birahi menampakkan kualitas birahi dengan ciri khas, yaitu labia minora memerah, vulva membengkak, suhu tubuh meningkat, berlendir (keluarnya mисиs atau lendir yang berasal dari cervix berwarna jernih atau bening) serta betina berdiri dan diam, apabila dinaiki pejantan (mounting). Listiani (2005) dan Endrawati, Baliarti dan Sasmito (2010) menjelaskan bahwa birahi pada sapi umumnya berlangsung selama 12-18 jam tergantung pada breed, paritas, umur dan musim. Sapi mempunyai lama birahi lebih pendek (10-12 jam) pada lingkungan dengan suhu panas, sedangkan lama birahi 
sapi di lingkungan beriklim dingin ratarata 18 jam.

Pengamatan birahi pada sapi betina mempengaruhi tinggi rendahnya nilai NRR, seperti warna dan suhu vulva yang sesuai dengan kondisi birahi (vulva kemerahan, vulva bengkak dan suhu vulva lebih tinggi dari suhu tubuh normal sapi). Warna vulva memerah menandakan ternak birahi kembali, suhu vulva berkisar antara 37$38^{\circ} \mathrm{C}$, kondis vulva bengkak dan beberapa ternak betina mengeluarkan lendir bening yang menggantung berwarna bening di vulva. Suhu vulva diukur menggunakan termometer digital $\left({ }^{\circ} \mathrm{C}\right)$ yang dimasukkan dalam vulva selama tiga menit saat birahi dan diperoleh suhu rata-rata sebesar 37- $39^{\circ} \mathrm{C}$. Pengamatan birahi berdasarkan keadaan vulva dan lendir cervix dengan kualitas birahi $3 \mathrm{~A}+, 2 \mathrm{~A}+$ dan $\mathrm{A}+$. Birahi dengan kualitas $(3 \mathrm{~A}+)$ ditandai dengan labia minora memerah,vulva membengkak, suhu tubuh meningkat dan lendir banyak, kental dan bening; kualitas (2A+) labia minora memerah, vulva tidak membengkak suhu tubuh meningkat serta lendir sedikit, bening danencer; $(\mathrm{A}+)$ labia minora memerah, vulva tidak membengkak, suhu normal dan lender sedikit sekali. Kualitas birahi ternak betina yang diinseminasi dengan semen beku dan cair tersaji pada Tabel 3.

Tabel 3. Kualitas birahi sapi induk yang di inseminasi menggunakan semen beku kontrol (P1) dan cair dengan $0,6 \%$ BSA $(\mathrm{P} 2)$

\begin{tabular}{cccccc}
\hline \multirow{2}{*}{ Pemeriksaan Kebuntingan } & Kualitas Birahi & \multicolumn{2}{c}{ Semen Beku $(\mathrm{P} 1)$} & \multicolumn{2}{c}{ Semen Cair (P2) } \\
\cline { 3 - 6 } & & $\begin{array}{c}\text { Jumlah } \\
\text { (ekor) }\end{array}$ & $\%$ & $\begin{array}{c}\text { Jumlah } \\
\text { (ekor) }\end{array}$ & $\%$ \\
\hline \multirow{3}{*}{ Positif } & $3 \mathrm{~A}+$ & 17 & 89,47 & 15 & 78,94 \\
& $2 \mathrm{~A}+$ & 0 & 0 & 0 & 0 \\
& $\mathrm{~A}+$ & 0 & 0 & 0 & 0 \\
\hline \multirow{3}{*}{ Negatif } & $3 \mathrm{~A}+$ & 1 & 5,26 & 3 & 15,78 \\
& $2 \mathrm{~A}+$ & 1 & 5,26 & 1 & 5,26 \\
& $\mathrm{~A}+$ & 0 & 0 & 0 & 0 \\
\hline
\end{tabular}

Hasil penelitian menunjukkan bahwa sapi betina yang positif bunting tertinggi dengan kualitas birahi 3A+ menggunakan semen beku sebanyak 17 ekor $(89,47 \%)$ dan IB menggunakan semen cair sebanyak 15 ekor $(78,94 \%)$. Hasil tersebut menunjukkan bahwa kualitas birahi dan ketepatan waktu IB meningkatkan persentase kebuntingan sapi betina. Waktu IB terbaik pada sapi dilakukan pada akhir fase metestrus, karena mendekati waktu ovulasi ovum. Spermatozoa mengalami kapasitasi di uterus setelah deposisi semen sebelum memfertilisasi ovum. Spermatozoa dengan morfologi utuh dan terkapasitasi sempurna yang mampu memfertilisasi ovum.

Waktu birahi tidak dapat ditentukan dengan pasti, tetapi dapat dilihat dari tanda-tanda birahi yang muncul. Penentuan waktu IB dapat ditentukan, sebagai berikut: apabila sapi betina menampakkan tandatanda birahi pada pagi hari, maka sapi tersebut dikawinkan pada sore hari. Sapi betina yang menunjukkan tanda-tanda birahi sore hari, maka sapi betina dikawinkan pada pagi hari berikutnya (Annashru, et al. 2017).

\section{Evaluasi Keberhasilan IB berdasarkan- Nilai Service per Conception (S/C)}

Nilai S/C merupakan salah satu ukuran keberhasilan IB yang menunjukkan jumlah perkawinan atau IB yang dibutuhkan sapi betina sampai terjadi kebuntingan dan sering digunakan sebagai pedoman keberhasilan IB di lapang dribandingkan 
dengan NRR dan CR. Fertilitas ternak betina di suatu wilayah yang menggunakan system perkawinan IB juga dapat diukur berdasarkan nilai S/C. Hasil pengamatan S/C selama penelitian tersaji pada Tabel 4.

Tabel 4. Nilai S/C hasil aplikasi IB menggunakan semen beku dan cair

\begin{tabular}{clcc}
\hline No. & Jenis semen & Jumlah Sapi Induk (ekor) & S/C \\
\hline 1. & Beku Kontrol (P1) & 17 & 1,29 \\
2. & Cair (P2) & 15 & 1,6 \\
\hline
\end{tabular}

Hasil analisa statistik menunjukkan bahwa nilai S/C hasil IB semen beku dan cair tidak berbeda nyata, sedangkan hasil pengamatan nilai $\mathrm{S} / \mathrm{C}$ hasil IB menggunakan semen beku (1,29) lebih rendah dibandingkan dengan nilai $\mathrm{S} / \mathrm{C}$ menggunakan semen cair $(1,6)$. Hal ini diduga motilitas post thawing spermatozoa semen beku lebih tinggi (40\%) dibandingkan semen cair (30\%), sehingga berpengaruh terhadap keberhasilan kebuntingan sapi betina atau akseptor IB.

Jainudeen dan Hafez (2008) menjelaskan bahwa nilai S/C yang normal berkisar antara 1,6-2,0 dan semakin rendah nilai $\mathrm{S} / \mathrm{C}$, maka semakin rendah tingkat kesuburannya. Iswoyo dan Widyaningrum (2008) menambahkan bahwa penyebab tingginya nilai S/C adalah (1) Peternak terlambat mendeteksi kemunculan birahi dan terlambat melaporkan kepada inseminator, (2) Adanya kelainan pada organ reproduksi induk sapi, (3) Inseminator kurang trampil, (4) Fasilitas pelayanan inseminasi yang terbatas dan (5) Kurang lancarnya transportasi. Hal ini didukung oleh Hartatik, dkk (2009) bahwa tingginya nilai S/C disebabkan oleh peternak maupun petugas IB terlambat dalam mendeteksi birahi serta waktu IB yang tidak tepat. Faktor kesuburan ternak juga sangat berpengaruh, seperti: sapi lokal cenderung mempunyai kesuburan lebih tinggi dibandingkan dengan sapi keturunan bangsa eksotik dan sapi keturunan bangsa eksotik lebih baik dikawinkan alam (menggunakan pejantan pemancek).

Tinggi rendahnya nilai $\mathrm{S} / \mathrm{C}$ juga dipengaruhi oleh deposisi semen di dalam uterus pada pelaksanaan IB. Deposisi semen pada penelitian ini dilakukan di posisi 4+ (di daerah cornua uteri) yang bertujuan agar spermatozoa segera mengalami fertilisasi dengan ovum di ampullary isthmic junction (bagian dari oviduct atau tuba fallopii). Penelitian Susilawati $\left(2011^{\mathrm{a}}\right)$ menjelaskan bahwa nilai S/C sebesar 1,2 deposisi semen pada posisi 4+ dengan PTM $\geq 40 \%$ dan nilai $\mathrm{S} / \mathrm{C} 1,44$ dengan deposisi semen 4+ dengan PTM 30-40\%. Faktor lain yang mempengaruhi tingginya nilai S/C dalam penelitian ini adalah deteksi birahi kurang akurat oleh peternak dan sering terjadinya silent heat. Kebiasaan peternak yang jarang mengeluarkan ternak dari kandang menyebabkan ternak kurang exercise (bergerak) dan mendapat sinar matahari. Lingkungan kandang yang kotor dan lembab berakibat pada lendir kurang terdeteksi sebagai indikator birahi yang umumnya menempel pada bagian pantat sapi lebih sulit untuk diidentifikasi, karena lendir telah bercampur dengan kotoran di dalam kandang. Kondisi demikian diduga sebagai penyebab ternak di lokasi penelitian mengalami gangguan dari ektoparasit maupun endoparasit. Hal ini didukung oleh Susilawati $\left(2011^{\mathrm{b}}\right)$ menjelaskan bahwa ternak yang terkena gangguan ektoparasit atau endoparasit akan terganggu siklus reproduksinya, karena ternak mengalami stress dan gejala yang paling sering tampak adalah silent heat (tidak muncul tanda-tanda birahi), tidak ovulasi atau terjadinya kematian embrio.

Perbaikan pakan, baik kualitas maupun kualitas, merupakan salah satu cara untuk mencegah silent heat pada ternak. 
Pakan yang diberikan peternak di tempat penelitian berasal dari sekitar area persawahan dan tempat tinggal berupa limbah pertanian, seperti jerami padi, daun tebu, tebon jagung dan rumput gajah dan tanpa pakan tambahan, seperti konsentrat. Hartatik, dkk. (2009) menyatakan bahwa kualitas pakan yang kurang bagus dan jumlah pakan yang kurang dapat mengganggu proses reproduksi pada ternak yang barakibat pada siklus estrus atau birahi yang panjang, kegagalan kebuntingan dan kematian embrio.

\section{Evaluasi Keberhasilan IB berdasarkan Nilai Conception Rate (CR)}

Indikator keberhasilan IB dapat ditentukan melalui nilai CR, yaitu persentase sapi betina yang bunting pada inseminasi pertama dari keseluruhan jumlah ternak betina yang di inseminasi atau disebut angka konsepsi (Yulyanto dkk., 2014). Nilai CR dikatakan baik, apabila nilainya lebih dari 60\% (Ihsan dan Wahjuningsih, 2011). Hasil pengamatan CR di lokasi selama penelitian tersaji pada Tabel 5 .

Tabel 5. Nilai CR hasil IB menggunakan semen beku dan cair

\begin{tabular}{clcc}
\hline No. & \multicolumn{1}{c}{ Jenis semen } & Jumlah sapi induk (ekor) & CR (\%) \\
\hline 1. & Beku kontrol (P1) & 17 & 89,47 \\
2 & Cair (P2) & 15 & 78,94 \\
\hline
\end{tabular}

Hasil analisa statistik menjelaskan bahwa tidak ada perbedaan nyata hasil aplikasi IB pada sapi betina menggunakan semen beku dan cair. Nilai CR hasil pengamatan pada ternak betina yang di inseminasi dengan semen beku $(89,47 \%)$ lebih tinggi dibandingkan ternak betina yang di inseminasi dengan semen cair $(78,94 \%)$. Hal tersebut diduga disebabkan oleh PTM semen beku lebih tinggi dibandingkan motilitas semen cair, sehingga kemampuan spermatozoa dari semen beku untuk memfertilisasi ovum lebih tinggi dibandingkan spermatozoa dari semen cair. Motilitas atau gerak progresif spermatozoa mempunyai peran penting dalam proses fertilisasi dengan ovum, karena hanya spermatozoa dengan motilitas tinggi yang mampu memfertilisasi ovum dan menghasilkan angka konsepsi atau kebuntingan yang tinggi.

Nilai CR dalam penelitian ini lebih tinggi dibandingkan hasil penelitian Fernanda. Susilawati dan Isnaini (2014) bahwa nilai CR pada Sapi PO sebesar 74,07\% menggunakan semen beku non sexing (P0) dengan PTM $\geq 40 \%$ dan di inseminasi pada posisi 4+. Sapi PO yang di inseminasi dengan semen beku sexing (P1) mempunyai nilai CR sebesar 55,56\% dengan kualitas PTM 5-10\% dan IB dilakukan pada posisi 4+. Nilai CR penelitian lebih rendah dibandingkan dengan penelitian Susilawati $\left(2011^{\mathrm{a}}\right)$ bahwa CR pada Sapi PO sebesar $80 \%$ pada empat perlakuan yang berbeda dan IB dilakukan pada posisi 4+ menggunakan semen beku (PTM $\geq 40 \%$ ). Rendahnya nilai CR pada semen cair besar diduga disebabkan oleh kualitas spermatozoa menurun selama proses pengenceran dan pengiriman dari laboratorium menuju lapang untuk di inseminasi pada sapi betina. Da Costa, dkk. (2016) menyatakan bahwa persentase minimal standar motilitas individu semen segar adalah $65 \%$ dan semen cair sebesar $\geq 40 \%$.

Pemeriksaan kebuntingan (PKB) pada hari ke-60 setelah IB dapat membuktikan keakuratan nilai CR. Hal ini didukung oleh Fanani, Subagyo dan Lutojo (2013) dan Verma, et al. (2014) bahwa pemeriksaan kebuntingan pada ternak dapat dilakukan 3-4 bulan setelah IB oleh inseminator atau petugas yang berpengalaman. Nilai CR baik berdasarkan kondi- 
si di Indonesia adalah 60-70\% dan nilai CR berdasarkan pertimbangan kondisi alam, manajemen dan distribusi ternak yang menyebar dianggap baik, apabila CR mencapai $40-50 \%$.

Kondisi fisiologis dari ternak betinaakseptor merupakan salah satu faktor yang menentukan keberhasilan IB. Body Condition Score (BCS) pada ternak betina merupakan kondisi fisiologis yang erat kaitannya dengan keberhasilan kebuntingan. Kondisi BCS pada penelitian ini berkisar antara tiga dan 4 memiliki tingkat keberhasilan kebuntingan yang lebih tinggi baik semen beku maupun semen cair. Rata-rata akseptor betina yang bunting pada pengamatan CR memiliki BCS 3 dan 4 (Tabel 6).

Tabel 6. Skor BCS sapi betina yang di inseminasi menggunakan semen beku dan semen cair

\begin{tabular}{|c|c|c|c|c|c|}
\hline \multirow{2}{*}{ Bunting } & \multirow{2}{*}{ Skor BCS } & \multicolumn{2}{|c|}{ Semen Beku Kontrol (P1) } & \multicolumn{2}{|c|}{ Semen Cair (P2) } \\
\hline & & Jumlah (ekor) & $\%$ & Jumlah (ekor) & $\%$ \\
\hline \multirow[t]{4}{*}{ Positif } & 5 & 1 & 5,27 & 0 & 0 \\
\hline & 4 & 1 & 5,27 & 2 & 10,54 \\
\hline & 3 & 14 & 73,78 & 13 & 68,51 \\
\hline & 2 & 1 & 5,27 & 0 & 0 \\
\hline \multirow[t]{4}{*}{ Negatif } & 5 & 1 & 5,27 & 0 & 0 \\
\hline & 4 & 0 & 0 & 1 & 5,27 \\
\hline & 3 & 1 & 5,27 & 3 & 15,81 \\
\hline & 2 & 0 & 0 & 0 & 0 \\
\hline
\end{tabular}

Hasil penelitian menunjukkan bahwa ternak positif bunting yang di inseminasi dengan semen beku (BCS 2) sebanyak satu ekor $(5,27 \%)$, BCS 3 sebanyak 14 ekor $(73,78 \%)$, BCS 4 sebanyak satu ekor $(5,27 \%)$ dan BCS 5 sebanyak satu ekor $(5,27 \%)$. Sapi betina yang positif bunting di inseminasi menggunakan semen cair dengan BCS 2 dan 5 tidak menunjukkan adanya ternak yang bunting, BCS 3 sebanyak 13 ekor $(68,51 \%)$, BCS 4 sebanyak dua ekor $(10,54 \%)$. Sapi betina dengan BCS 3 lebih sering menunjukkan tanda-tanda birahi dibandingkan dengan ternak dengan BCS lainnya yang di inseminasi dengan semen cair. Ukuran BCS yang rendah diindikasikan ternak tersebut belum terpenuhi kebutuhan nutrisinya, sehingga berdampak terhadap keberhasilan kebuntingan dan efisiensi reproduksi ternak. Susilawati $\left(2011^{\mathrm{b}}\right)$ menyatakan bahwa ukuran BCS induk mempengaruhi keberhasilan kebuntingan pada ternak. Induk yangmemiliki BCS terlalu kurus akan mengalami kesulitan dalam bereproduksi atau angka kebuntingan rendah.

Penampakan tanda-tanda birahi tersebut diawali dengan adanya rangsangan dari luar (lingkungan) terhadap indera (penglihatan, pendengaran, penciuman dan perasa) yang diterima oleh hipotalamus, selanjutnya hipotalamus memerintahkan pituitary atau hipofisa anterior untuk mensekresi Follicle Stimulating Hormone (FSH) dan Luteinizing Hormone (LH) untuk pertumbuhan dan pematangan folikel di ovarium, sehingga folikel di bagian cortex ovarium mensekresikan hormon estrogen. Hormon tersebut memberikan pengaruh umpan balik pada hipotalamus untuk memberi sinyal agar hipofisa anterior mensekresikan Adreno Corticothropic Hormone (ACTH) menuju kelenjar adrenal, sehingga disekresikan hormon adrenalin dan kortisol. Hormon adrenalin menyebabkan penyempitan pembuluh darah dan memicu aktivitas denyut jantung, sehingga tekanan darah meningkat dan memberi sinyal pada hipotalamus untuk 
memberi respon tingkah laku gelisah. Hormon kortisol menyebabkan tingginya kadar gula dalam darah dan meningkatkan hormon leptin yang dapat menurunkan nafsu makan. Hal ini sesuai dengan pendapat Setiawan, Samsudewa dan Sutiyono (2015) bahwa hormon adrenalin muncul akibat adanya aktivitas berlebih ketika birahi, seperti gelisah, dapat mempercepat aliran darah dan matabolisme yang berhubungan dengan suplai kebutuhan energi dalam tubuh.

\section{Kesimpulan}

Berdasarkan hasil penelitian dapat di simpulkan bahwa semen cair menggunakan pengencer $\mathrm{CEP}-2+0,6 \% \mathrm{BSA}$ menghasilkan kebuntingan tinggi berdasarkan nilai NRR, CR dan S/C pada induk sapi potong. Induk sapi dengan BCS 3 lebih sering menunjukkan tanda-tanda birahi. Penelitian lebih lanjut dibutuhkan untuk mempertahankan kualitas semen cair dari laboratorium ke lapang.

\section{References}

Aboagla, EM-E and T. Terada. 2004. Effects of egg yolk during the freezing step of cryopreservation on the viability of goat spermatozoa. Theriogenology 62(6): 1160-1172.

Annashru, F. A., M. N. Ihsan., A. P. A. Yekti dan T. Susilawati. 2017. Pengaruh Perbedaan Waktu Inseminasi Buatan terhadap Keberhasilan Kebuntingan Sapi Brahman Cross. Jurnal IlmuIlmu Peternakan, 27(3): 17-23.

Da Costa, N., T. Susilawati, N. Isnaini and M.N. Ihsan, 2016. Effect of Different Dilution Materials Usage on Indonesian Peranakan Ongole Bull Sperm Quality During Cooling Process. Indo American Journal of Pharmaceutical Sciences, 3(4): 379-385.
Delgado, P.A., T.D. Lester and R.W. Rorie, 2009. Effet of LowSodium, Choline-Based Diluents on Viability of Bovine Sperm Stored at refrigerator temperatures. AAES Research Serie, 574: 77-79.

Endrawati, E., E. Baliarti, dan S. P. B. Sasmito. 2010. Performans Induk Sapi Silangan SimentalPeranakan Ongole dan Induk Sapi Peranakan Ongole dengan Pakan Hijauan dan Konsentrat. Buletin Peternakan, 34(2): 7-89.

Fanani, S., Y. B. P. Subagyo dan Lutojo. 2013. Kinerja Reproduksi Sapi Peranakan Friesian Holstein (PFH) di Kecamatan Pudak, Kabupaten Ponorogo. Jurnal Tropical of Animal Husbandry, 2(1): 21-27.

Fernanda, M. T., T. Susilawati dan N. Isnaini. 2014. Keberhasilan IB menggunakan Semen Beku Hasil Sexing Dengan Metode Sentrifugasi Gradien Densitas Percoll (SGDP) pada Sapi Peranakan Ongole (PO). Jurnal Ilmu-Ilmu Peternakan, 24(3): 1-8.

Gillan, L., W.M.C. Maxwell and G. Evans, 2004. Preservation and Evaluation of Semen for Artificial Insemination. In Reproduction, Fertility and Development: 447-452.

Hartatik, T., D. A. Mahardika, T. S.M. Widi dan E. Baliarti. 2009. Karakteristik dan kinerja induk Sapi Silangan-Limousine Madura dan Madura di Kabupaten Sumenep dan Pamekasan. Buletin Peternakan, 33(3): 2528. 
Ihsan, M.N. dan S. Wahjuningsih. 2011. Penampilan Reproduksi Sapi Potong di Kabupaten Bojonegoro. J. Ternak Tropika, 12(2): 7680.

Iswoyo dan P. Widiyaningrum. 2008. Performanan Reproduksi Sapi Peranakan Simental (Psm) Hasil Inseminasi Buatan di Kabupaten Sukoharjo Jawa Tengah. Jurnal Ilmiah Ilmu-Ilmu Peternakan, 11(3): 125-133.

Jainudeen, M.R. and E.S.E. Hafez. 2008. Cattle and Buffalo in Reproduction in Farm Animals. $7^{\text {nd }}$ Edition. Lippinoctt Williams \& Wilkins. Maryland.USA.

Kaeoket, K., P. Chanapai, P. Junchiyaphoom and P. Chanapiwat, 2011. The effect of Using Long and Short Term Extendrs during Cooling Process on The Quality of Frozen Boar Semen. Thai. J. Vet. Med, 41 (3): 283-288.

Landim-Alvarenga, F.C., J.K. Graham, M.A. Alvarenga and E.L. Squires, 2004. Calcium influx into equine and bovine spermatozoa during in vitro capacitation. J. Anim. Reprod, 1(1) : 96-105.

Listiani, D. 2005. Pemberian PGF2 $\alpha$ pada Sapi Peranakan Ongole yang Mengalami Gangguan Corpus Luteum Persis-ten. Jurnal Veteriner, 15(1): 33-43.

Lobo V., A. Patil, A. Pathak and N. Chandra, 2010. Free Radicals, antioxidant and functional food: Impacts on human health. Pharmacogn, 4(8): 118-126.
Osman, K., C.F. Nang, S.F. Ibrahim, S.B. Budin, F.H.F. Jaffar and N.A.A. Wahab, 2012. Albumin Improved Spermatozoa Quality and DNA Integrity for Freezing-Free Preservation. Intl. J. Biol. Med. Res., 3(2): 1670-1679.

Peris, S.I., J.F. Bilodeau., M. Dufour and J.L. Bailey. 2007. Impact of cryopreservation and reactive oxygen species on DNA integrity, lipid peroxidation, and functional parameters in ram sperm. Molecular Reproduction and Development, 74 : 878-892.

Ponglowhapana, S., B. Esse'n-Gustavssonb and C.L. Forsberga, 2004. Influence of Glucose and Fructose in The Extender during Long-Term Storage of Chilled Canine Semen. Theriogenology, 62 : 1498-1517.

Ratnawati, D., D.A, Indrakusuma, L. Affandhy, F. Cowley, D. Mayberry and D. Poppi, 2016. Management Strategies to Improve Reproductive Performance of Brahman Cross Cattle (Bos indicus) in East Java, Indonesia. JITV, 21(4) : 231-23

Royal, M.D., A.O.Darwash, A.P.F.Flint, R.Webb, J.A.Woolliams, and G.E.Lamming. 2000. Declining Fertility in Dairy Catle: Changes in Traditional and Endrocine $\mathrm{Pa}$ rameters of Fertility. Journal Animal Science, 92(8): 4001-4007.

Setiawan, I.A., D. Samsudewa dan Sutiyono. 2015. Pengaruh jumlah pejantan perkandang terhadap tingkah laku reproduksi Rusa Timor (Rusa Timorensis) betina. Agromedia, 33(2): $71-$ 77. 
Simbolon, I.S., T.M. Lubis dan M. Adam, 2013. Persentase Spermatozoa hidup pada Tikus Wistar dan Spraguue-Dawley. Jurnal Medika Veterinaria, 7(2): 79-83.

Supartini, N. dan H. Darmawan, 2014. Profil Genetik dan Peternak Sapi Ongole sebagai Strategi Dasar Pengembangan Desa Pusat Bibit Ternak. Buana Sains, 14(1) : 1784.

Supranto, J. 2012. Statistik Teori dan Aplikasi. Edisi Ketujuh. Erlangga. Bandung.

Susilawati, T. 2005. Tingkat Keberhasilan Kebuntingan dan Ketepatan Jenis Kelamin HasilInseminasi Buatan menggunakan Semen Beku Sexing pada Sapi Peranakan Ongole. Animal Production, 7(3) : 161-164.

Susilawati, T. 2011 a . Tingkat Keberhasilan Inseminasi Buatan Dengan Kualitas dan Deposisi Semen yang Berbeda pada Sapi Peranakan Ongole. Jurnal Ternak Tropika, 12(2) : 15-24.

Susilawati, T. 2011 ${ }^{\mathrm{b}}$. Spermatologi. Malang : UB Press.

Susilawati, T., N. Isnaini, A.P.A. Yekti, I. Nurjanah, Errico dan N. da Costa, 2016. Keberhasilan inseminasi buatan menggunakan semen beku dan semen cair pada Sapi Peranakan Ongole. Jurnal Ilmu-Ilmu Peternakan, 26(3) : 14-19.

Susilawati, T.. 2013. Pedoman Inseminasi Buatan pada Ternak. Malang : UB Press.
Susilawati, T. 2017. Sapi Lokal Indonesia (Jawa Timur dan Bali). Malang : UB Press.

Verberckmoes, S., A.V. Soom, I.D. Pauw, and A D. Kruif. 2004. Storage of Fresh Bovine Semen in A Diluent Based of Cauda Epididymal Plasma. Chapter 4. Reproduction in Domestic Animals, 39: 1-7.

Verma, K. K., S. Prasad, A. Kumaresan, T. K. Mohanty, S. S. Layek, T. K. Patbandha and S. Chand. 2014. Characterization of Physicochemical Properties of Cervical Mucus in Relation to Parity and Conception Rate in Murrah Buffaloes. Veterinary World, 7(7): 467-471.

Yamashiro, H., H. wang, Y. Yamashita, K. Kumamoto, and T.Terada. 2006. Enhanced Freezability of Goat Spermatozoa Collected into Tubes Containing Extender Supplemented with Bovine Serum Albumin (BSA). Journal of Reproduction and Development, 52 : 407-414.

Yulyanto, C. A., T., Susilawati dan S., Wahyuningsih. 2014. Penampilan Reproduksi Sapi Peranakan Ongole (PO) dan Sapi Peranakan Limousin di Kecamatan Sawoo, Kabupaten Ponorogo dan Kecamatan Tugu Kabupaten Trenggalek. Jurnal Ilmu-Ilmu Peternakan, 24(2) : 49-57. 